\title{
Model documentation
}

In the following, we describe the main processes of the simulation model in a structured form based on the ODD+D protocol (Müller et al., 2013). A conceptual diagram of the model entities and their relationships is shown in Fig $\mathrm{S} 1$.

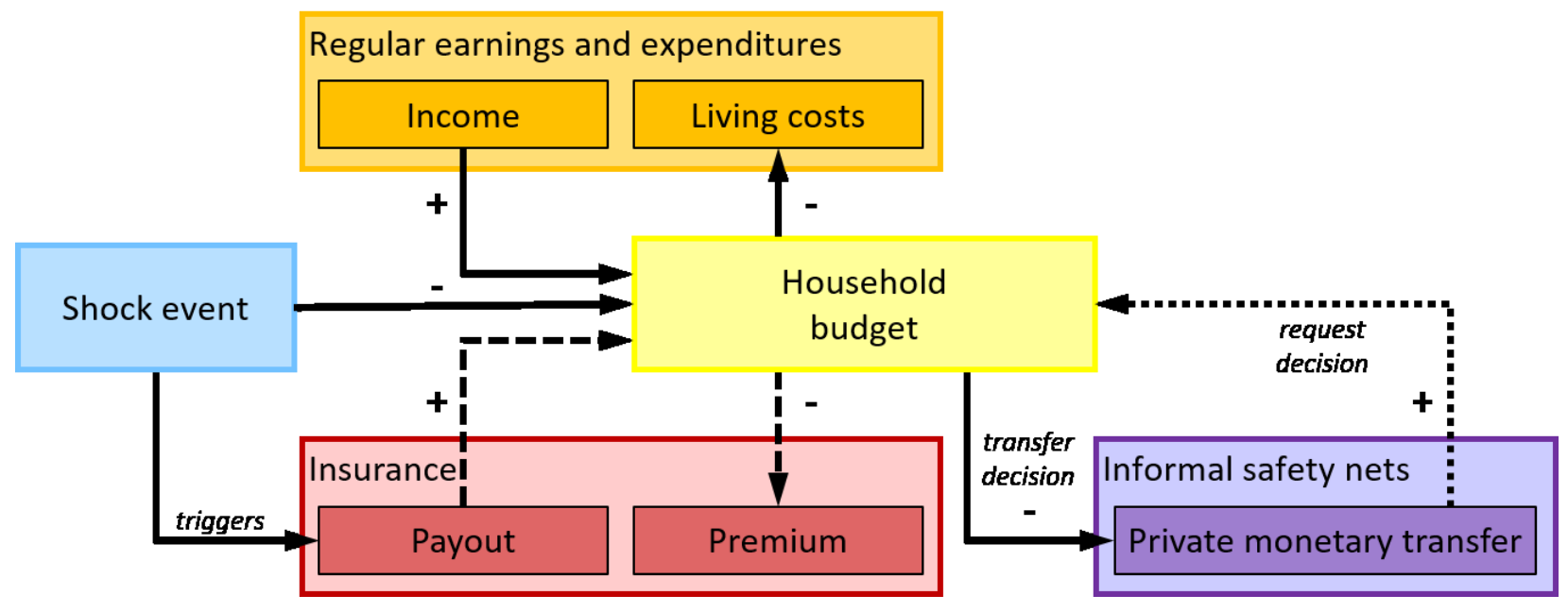

Fig S1. Conceptual diagram of the model showing the household budget, its main drivers and their relationships. Longdashed relations are only important for insured households, short-dashed relations only for uninsured households. 


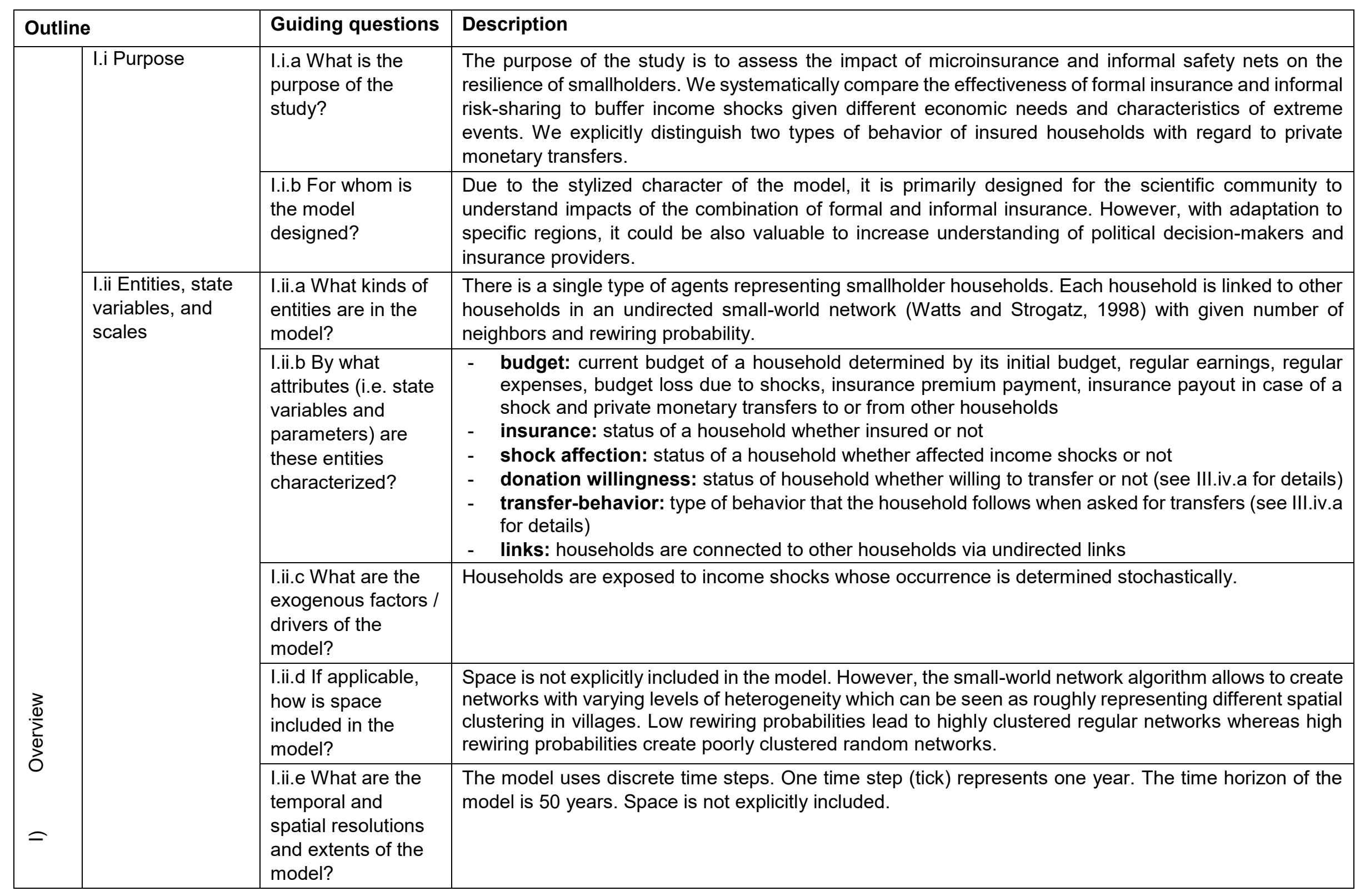




\begin{tabular}{|c|c|c|c|}
\hline & $\begin{array}{l}\text { I.iii Process } \\
\text { overview and } \\
\text { scheduling }\end{array}$ & $\begin{array}{l}\text { I.iii.a What entity } \\
\text { does what, and in } \\
\text { what order? }\end{array}$ & $\begin{array}{l}\text { - Initialization: set up of households (initial budget, insurance status, donation willingness) and small- } \\
\text { world network } \\
\text { - In every tick: } \\
\text { - All households (synchronous): } \\
\text { - Budget increases by income and decreases by annual living costs } \\
\text { - Insured households: pay insurance premium } \\
\text { - Insured households affected by shock: receive payout } \\
\text { - Households in need request transfers from randomly chosen households they are } \\
\text { - Requested households transfer money to requesting households according to } \\
\text { transfer behavior } \\
\text { Check for surviving households: If household's budget is below zero, household has to } \\
\text { leave the system. }\end{array}$ \\
\hline \multirow{3}{*}{ 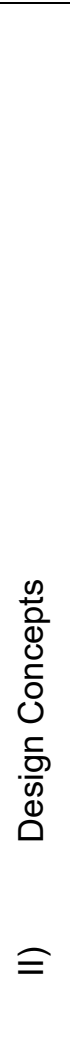 } & \multirow[t]{3}{*}{$\begin{array}{l}\text { Il.i Theoretical } \\
\text { and Empirical } \\
\text { Background }\end{array}$} & $\begin{array}{l}\text { II.i.a Which general } \\
\text { concepts, theories } \\
\text { or hypotheses are } \\
\text { underlying the } \\
\text { model's design at } \\
\text { the system level or } \\
\text { at the level(s) of the } \\
\text { submodel(s) (apart } \\
\text { from the decision } \\
\text { model)? What is } \\
\text { the link to } \\
\text { complexity and the } \\
\text { purpose of the } \\
\text { model? }\end{array}$ & $\begin{array}{l}\text { - We assume that households have access to formal insurance and traditional informal safety nets to } \\
\text { secure themselves against income shocks. These shocks can be idiosyncratic shocks, hitting the } \\
\text { households independently (such as health shocks), or covariate shocks, affecting many households } \\
\text { at the same time (such as drought shocks). } \\
\text { - Complexity results from the feedback between the dynamics of the budget of individual households } \\
\text { and monetary transfers between households in networks. } \\
\text { - By explicitly including two types of behavior of insured households with regard to private monetary } \\
\text { transfers, the model contributes to the debate of unintended side effects of formal insurance } \\
\text { schemes and helps to identify long-term effects and structural peculiarities that influence the } \\
\text { outcome. }\end{array}$ \\
\hline & & $\begin{array}{l}\text { II.i.b On what } \\
\text { assumptions is/are } \\
\text { the agents' decision } \\
\text { model(s) based? }\end{array}$ & $\begin{array}{l}\text { The decision models for transfer provision are based on observations from case studies and reflect } \\
\text { behavior with and without solidarity of insured households. }\end{array}$ \\
\hline & & $\begin{array}{l}\text { II.i.c Why is a/are } \\
\text { certain decision } \\
\text { model(s) chosen? }\end{array}$ & $\begin{array}{l}\text { Empirical observations show mixed results with respect to the transfer behavior of insured households. } \\
\text { Therefore, we have chosen two strategies of transfer decisions which reflect behavior with and without } \\
\text { solidarity towards uninsured households. In one simulation run, all households decide on their transfers } \\
\text { according to the same strategy. For the first strategy, all households show solidarity, i.e. they transfer } \\
\text { whenever they can afford it. In a second strategy, we assume that only uninsured households show } \\
\text { solidarity and contribute to informal risk-sharing whenever they can afford it; insured households do not }\end{array}$ \\
\hline
\end{tabular}




\begin{tabular}{|c|c|c|}
\hline & & $\begin{array}{l}\text { transfer at all. We have implemented the two decision rules to compare the effects of both behaviors on } \\
\text { the resilience of smallholders. }\end{array}$ \\
\hline & $\begin{array}{l}\text { Il.i.d If the model / a } \\
\text { submodel (e.g. the } \\
\text { decision model) is } \\
\text { based on empirical } \\
\text { data, where does } \\
\text { the data come } \\
\text { from? }\end{array}$ & $\begin{array}{l}\text { Most parts of the model are not directly based on empirical data. The values of household characteristics } \\
\text { are chosen in a range derived from literature on microinsurance and informal transfer networks in } \\
\text { different countries (for specific references see III.iv.b). Furthermore, the combined parameter space for } \\
\text { income, living costs, shock probability and shock intensity is reduced based on economic constraints (for } \\
\text { details see III.iv.c). }\end{array}$ \\
\hline & $\begin{array}{l}\text { Il.i.e At which level } \\
\text { of aggregation were } \\
\text { the data available? }\end{array}$ & Not applicable. \\
\hline \multirow{3}{*}{$\begin{array}{l}\text { Il.ii Individual } \\
\text { Decision Making }\end{array}$} & $\begin{array}{l}\text { II.ii.a What are the } \\
\text { subjects and } \\
\text { objects of decision- } \\
\text { making? On which } \\
\text { level of aggregation } \\
\text { is decision-making } \\
\text { modeled? Are } \\
\text { multiple levels of } \\
\text { decision making } \\
\text { included? }\end{array}$ & $\begin{array}{l}\text { There is one level of decision making, the household level. Households are the subject of decision } \\
\text { making. The monetary transfer provision from wealthy households to households in need in the network } \\
\text { is the object. }\end{array}$ \\
\hline & $\begin{array}{l}\text { II.ii.b What is the } \\
\text { basic rationality } \\
\text { behind agents' } \\
\text { decision-making in } \\
\text { the model? Do } \\
\text { agents pursue an } \\
\text { explicit objective or } \\
\text { have other success } \\
\text { criteria? }\end{array}$ & $\begin{array}{l}\text { - Transfer request: Each household's objective is to maintain prosperity with a budget above or equal } \\
\text { to zero. Households with a budget below zero request help from other agents with a budget above } \\
\text { zero in their network. } \\
\text { - Transfer provision: } \\
\text { - Solidarity: Households transfer whenever they can afford it (i.e. have a budget above zero). } \\
\text { This implies that households may assume that the requesting household will return the } \\
\text { transfer in the future if they need support themselves. Since, in the simulated scenarios, } \\
\text { insurance covers all losses, this will only occur for uninsured households. } \\
\text { - No solidarity: Only uninsured households show solidarity and contribute to informal risk- } \\
\text { sharing whenever they can afford it (i.e. have a budget above zero); insured households do } \\
\text { not transfer at all. This implicitly includes that they are (1) not dependent on reciprocal } \\
\text { behavior of other households because shocks are fully covered by the insurance and (2) not } \\
\text { willing to transfer as they have more costs due to the insurance that uninsured households } \\
\text { avoided. }\end{array}$ \\
\hline & $\begin{array}{l}\text { II.ii.c How do } \\
\text { agents make their } \\
\text { decisions? }\end{array}$ & - $\quad$ Agents' decision rules are implemented as if-then rules. \\
\hline
\end{tabular}




\begin{tabular}{|c|c|c|}
\hline & & $\begin{array}{l}\text { - Transfer request: Households in need randomly pick one of the households in their network with } \\
\text { budget above zero. If the request cannot be fulfilled by one single agent, households continue } \\
\text { requesting the missing amount from other agents in their network. } \\
\text { - Transfer provision: Households that have been requested for a transfer decide how much to } \\
\text { transfer based on one of two decision rules: } \\
\text { - Solidarity: The transfer amount is determined by the request and their own budget. The } \\
\text { minimum budget of a donating household after the transfer is zero. } \\
\text { - No solidarity: Insured households do not transfer at all; uninsured households show } \\
\text { solidarity. In this case, the transfer amount is determined according to the same rules as for } \\
\text { solidarity. }\end{array}$ \\
\hline & $\begin{array}{l}\text { Il.ii.d Do the agents } \\
\text { adapt their behavior } \\
\text { to changing } \\
\text { endogenous and } \\
\text { exogenous state } \\
\text { variables? And if } \\
\text { yes, how? }\end{array}$ & $\begin{array}{l}\text { Yes. Households adapt the transfer amount to the requested amount and their own budget. It is } \\
\text { incorporated that donors do not put themselves at financial risk through transfers. Therefore, the } \\
\text { minimum budget of a donor after a transfer is zero. On the other hand, the household in need should not } \\
\text { get too rich through the help of others. The maximum budget that can be achieved through transfers is } \\
\text { thus also zero. }\end{array}$ \\
\hline & $\begin{array}{l}\text { II.ii.e Do social } \\
\text { norms or cultural } \\
\text { values play a role in } \\
\text { the decision- } \\
\text { making process? }\end{array}$ & Transfer behavior with solidarity is implicitly based on expected reciprocity. \\
\hline & $\begin{array}{l}\text { II.ii.f Do spatial } \\
\text { aspects play a role } \\
\text { in the decision } \\
\text { process? }\end{array}$ & No, space is not explicitly included in the model. \\
\hline & $\begin{array}{l}\text { II.ii.g Do temporal } \\
\text { aspects play a role } \\
\text { in the decision } \\
\text { process? }\end{array}$ & Households make decisions based only on the current state of the system. \\
\hline & $\begin{array}{l}\text { Il.ii.h To which } \\
\text { extent and how is } \\
\text { uncertainty } \\
\text { included in the } \\
\text { agents' decision } \\
\text { rules? }\end{array}$ & Uncertainty is not included in the decision making. \\
\hline II.iii Learning & $\begin{array}{l}\text { Il.iii.a Is individual } \\
\text { learning included in } \\
\text { the decision }\end{array}$ & No, learning is not included. \\
\hline
\end{tabular}




\begin{tabular}{|c|c|c|}
\hline & $\begin{array}{l}\text { process? How do } \\
\text { individuals change } \\
\text { their decision rules } \\
\text { over time as } \\
\text { consequence of } \\
\text { their experience? }\end{array}$ & \\
\hline & $\begin{array}{l}\text { II.iii.b ls collective } \\
\text { learning } \\
\text { implemented in the } \\
\text { model? }\end{array}$ & No. \\
\hline \multirow{4}{*}{$\begin{array}{l}\text { II.iv Individual } \\
\text { Sensing }\end{array}$} & $\begin{array}{l}\text { II.iv.a What } \\
\text { endogenous and } \\
\text { exogenous state } \\
\text { variables are } \\
\text { individuals } \\
\text { assumed to sense } \\
\text { and consider in } \\
\text { their decisions? Is } \\
\text { the sensing } \\
\text { process erroneous? }\end{array}$ & $\begin{array}{l}\text { Households adapt their decision making to variables of households they are linked to in the network (see } \\
\text { II.iv.b). }\end{array}$ \\
\hline & $\begin{array}{l}\text { II.iv.b What state } \\
\text { variables of which } \\
\text { other individuals } \\
\text { can an individual } \\
\text { perceive? Is the } \\
\text { sensing process } \\
\text { erroneous? }\end{array}$ & $\begin{array}{l}\text { Requested households sense the amount asked for by the household in need. The sensing is not } \\
\text { erroneous, i.e. the households always perceive the true requested amount. Households in need do not } \\
\text { know the insurance status of their neighbors. }\end{array}$ \\
\hline & $\begin{array}{l}\text { II.iv.c What is the } \\
\text { spatial scale of } \\
\text { sensing? }\end{array}$ & $\begin{array}{l}\text { Not applicable directly as space is not explicitly included in the model. Concerning sensing in the network, } \\
\text { households include their direct neighbors in the network only. }\end{array}$ \\
\hline & $\begin{array}{l}\text { II.iv.d Are the } \\
\text { mechanisms by } \\
\text { which agents obtain } \\
\text { information } \\
\text { modeled explicitly, } \\
\text { or are individuals } \\
\text { simply assumed to }\end{array}$ & Agents are assumed to know the values of the sensed variables. \\
\hline
\end{tabular}




\begin{tabular}{|c|c|c|}
\hline & $\begin{array}{l}\text { know these } \\
\text { variables? }\end{array}$ & \\
\hline & $\begin{array}{l}\text { Il.iv.e Are costs for } \\
\text { cognition and costs } \\
\text { for gathering } \\
\text { information inclu- } \\
\text { ded in the model? }\end{array}$ & No. \\
\hline \multirow{3}{*}{$\begin{array}{l}\text { Il.v Individual } \\
\text { Prediction }\end{array}$} & $\begin{array}{l}\text { II.v.a Which data } \\
\text { uses the agent to } \\
\text { predict future } \\
\text { conditions? }\end{array}$ & Households do not predict future conditions. \\
\hline & $\begin{array}{l}\text { II.v.b What internal } \\
\text { models are agents } \\
\text { assumed to use to } \\
\text { estimate future } \\
\text { conditions or } \\
\text { consequences of } \\
\text { their decisions? }\end{array}$ & Not applicable. \\
\hline & $\begin{array}{l}\text { II.v.c Might agents } \\
\text { be erroneous in the } \\
\text { prediction process, } \\
\text { and how is it } \\
\text { implemented? }\end{array}$ & Not applicable. \\
\hline \multirow{3}{*}{ II.vi Interaction } & $\begin{array}{l}\text { Il.vi.a Are } \\
\text { interactions among } \\
\text { agents and entities } \\
\text { assumed as direct } \\
\text { or indirect? }\end{array}$ & $\begin{array}{l}\text { Interactions between households are direct. Households in need request money from households they } \\
\text { are linked to in the network which then decide how much to transfer. }\end{array}$ \\
\hline & $\begin{array}{l}\text { Il.vi.b On what do } \\
\text { the interactions } \\
\text { depend? }\end{array}$ & $\begin{array}{l}\text { Interactions depend on the budget of the household in need and the requested household as well as the } \\
\text { transfer decision and insurance status of the requested household. }\end{array}$ \\
\hline & $\begin{array}{l}\text { II.vi.c If the } \\
\text { interactions involve } \\
\text { communication, } \\
\text { how are such } \\
\text { communications } \\
\text { represented? }\end{array}$ & $\begin{array}{l}\text { Communication is represented by transfer request and provision. The transferred amount is reduced } \\
\text { from the budget of the giving household and added to the budget of the household in need. }\end{array}$ \\
\hline
\end{tabular}




\begin{tabular}{|c|c|c|}
\hline & $\begin{array}{l}\text { Il.vi.d If a } \\
\text { coordination } \\
\text { network exists, how } \\
\text { does it affect the } \\
\text { agent behavior? Is } \\
\text { the structure of the } \\
\text { network imposed or } \\
\text { emergent? }\end{array}$ & $\begin{array}{l}\text { - The network does not directly influence the behavior, but requests for transfers are only possible } \\
\text { between directly linked households. } \\
\text { - The network structure is imposed during the initialization of the model and is kept constant (i.e. } \\
\text { static) for a simulation run. }\end{array}$ \\
\hline \multirow[t]{2}{*}{ II.vii Collectives } & $\begin{array}{l}\text { Il.vii.a Do the } \\
\text { individuals form or } \\
\text { belong to } \\
\text { aggregations that } \\
\text { affect, and are } \\
\text { affected by, the } \\
\text { individuals? Are } \\
\text { these aggregations } \\
\text { imposed by the } \\
\text { modeler or do they } \\
\text { emerge during the } \\
\text { simulation? }\end{array}$ & $\begin{array}{l}\text { Households are connected in a network that influences their interaction range for monetary transfers. } \\
\text { The network is imposed during the initialization of the model and is kept constant (i.e. static) during the } \\
\text { simulation run. The network is based on a stylized small-world network. }\end{array}$ \\
\hline & $\begin{array}{l}\text { Il.vii.b How are } \\
\text { collectives } \\
\text { represented? }\end{array}$ & Collectives are represented as a network. \\
\hline \multirow{2}{*}{$\begin{array}{l}\text { Il.viii } \\
\text { Heterogeneity }\end{array}$} & $\begin{array}{l}\text { II.viii.a Are the } \\
\text { agents } \\
\text { heterogeneous? If } \\
\text { yes, which state } \\
\text { variables and/or } \\
\text { processes differ } \\
\text { between the } \\
\text { agents? }\end{array}$ & $\begin{array}{l}\text { All agents have the same set of state variables and processes. A fixed proportion of the households is } \\
\text { insured, the rest is uninsured. The population is homogeneous with all households having the same initial } \\
\text { budget, income level and annual living costs. }\end{array}$ \\
\hline & $\begin{array}{l}\text { II.viii.b Are the } \\
\text { agents } \\
\text { heterogeneous in } \\
\text { their decision- } \\
\text { making? If yes, } \\
\text { which decision } \\
\text { models or decision } \\
\text { objects differ }\end{array}$ & $\begin{array}{l}\text { Households take the same decisions on whom to ask for transfers and how much to transfer. However, } \\
\text { based on their insurance status, households' choices on transfer provision can be heterogeneous (see } \\
\text { Il.ii.b or III.iv.a). }\end{array}$ \\
\hline
\end{tabular}




\begin{tabular}{|c|c|c|}
\hline & $\begin{array}{l}\text { between the } \\
\text { agents? }\end{array}$ & \\
\hline II.ix Stochasticity & $\begin{array}{l}\text { Il.ix.a What } \\
\text { processes } \\
\text { (including } \\
\text { initialization) are } \\
\text { modeled by } \\
\text { assuming they are } \\
\text { random or partly } \\
\text { random? }\end{array}$ & $\begin{array}{ll}\text { - } & \text { Insurance status is assigned randomly. } \\
\text { - } & \text { Income shocks occur randomly (different for idiosyncratic and covariate shocks, see III.iv.a). } \\
\text { - } & \text { Households in need request transfers from households randomly chosen among the households } \\
\text { they are linked to in the network. }\end{array}$ \\
\hline II.x Observation & $\begin{array}{l}\text { II.x.a What data are } \\
\text { collected from the } \\
\text { ABM for testing, } \\
\text { understanding, and } \\
\text { analyzing it, and } \\
\text { how and when are } \\
\text { they collected? }\end{array}$ & $\begin{array}{l}\text { For parameter variations conducted with the R-package nlrx (Salecker et al., 2019), we collect for every } \\
\text { time step the states of (NetLogo variable names are given in brackets): } \\
\text { - Resilience: Fraction of surviving households (fraction-active) and surviving uninsured households } \\
\text { (fraction-active-uninsured) } \\
\text { - Budget: Total budget of all (total-budget), insured (total-budget-insured) and uninsured households } \\
\text { (total-budget-uninsured) and mean budget of all (mean-budget), insured (mean-budget-insured) and } \\
\text { uninsured households (mean-budget-uninsured) } \\
\text { - Transfer requests: Number of households that need help per time step (requesting-households), } \\
\text { the amount of money they need per time step (total-money-needed) and the total amount of money } \\
\text { needed up to that time step (cum-money-needed) } \\
\text { - Transfer provision: Total transfer given up to that time step by all (total-transfer), active (total- } \\
\text { transfer-active), insured (total-transfer-given-insured), uninsured (total-transfer-given-uninsured) } \\
\text { and uninsured active households (total-transfer-given-uninsured-active) and transfer received by } \\
\text { uninsured active households (total-transfer-received-uninsured-active) } \\
\text { - Inequality: GINI coefficient of all (get-gini), insured (get-gini-insured) and uninsured households } \\
\text { (get-gini-uninsured) } \\
\text { For each household, we collect for every time step: } \\
\text { - Budget: The total budget of a household (budget) and if a households' budget is above or equal to } \\
\text { zero (active) } \\
\text { Transfer: If a household is willing to provide transfers (donation-willingness), the total amount of } \\
\text { money received by (received) and transferred to (given) other households, the total number of } \\
\text { transfers (total-donates) and transfers per time step (current-donates) and the total number of } \\
\text { requests (total-requests) and requests per time step (current-requests) } \\
\text { Shock: Whether a household is affected by a shock in that time step (shock-affected) and how often } \\
\text { a household was affected by a shock (shock-affected-sum) }\end{array}$ \\
\hline
\end{tabular}




\begin{tabular}{|c|c|c|c|}
\hline & & & $\begin{array}{l}\text { For each link, we collect for every time step: } \\
\text { - Transfer: The total amount of money (total-flow) and the amount per time step (current-flow) } \\
\text { transferred between the two households in the direction of the link and the number of transfers on } \\
\text { that link (number-flows) } \\
\text { - Resilience: If a link is active, i.e. if both connected households have a budget above zero (active- } \\
\text { link) } \\
\text { In the graphical user interface, we plot the values of the following variables for each time step: } \\
\text { - Resilience: Fraction of surviving households (fraction-active) and surviving uninsured households } \\
\text { (fraction-active-uninsured) } \\
\text { - Budget: Mean budget of all (mean-budget), insured (mean-budget-insured) and uninsured } \\
\text { households (mean-budget-uninsured) } \\
\text { - Transfer provision: Current transfer per time step given by all, insured and uninsured households } \\
\text { - Inequality: GINI coefficient of all (get-gini), insured (get-gini-insured) and uninsured households } \\
\text { (get-gini-uninsured) }\end{array}$ \\
\hline & & $\begin{array}{l}\text { II.x.b What key } \\
\text { results, outputs or } \\
\text { characteristics of } \\
\text { the model are } \\
\text { emerging from the } \\
\text { individuals? } \\
\text { (Emergence) }\end{array}$ & $\begin{array}{l}\text { We can observe the effectiveness of formal and informal insurance given different economic needs } \\
\text { (income, living costs), characteristics of extreme events (shock probability, shock intensity, type of } \\
\text { shock), transfer behavior (solidarity, no solidarity) and network properties (average degree, rewiring } \\
\text { probability) on the resilience of the households, i.e. the fraction of surviving households, and their budget. }\end{array}$ \\
\hline \multirow{4}{*}{$\frac{\infty}{\stackrel{0}{\bar{d}}}$} & \multirow{2}{*}{$\begin{array}{l}\text { III.i } \\
\text { Implementation } \\
\text { Details }\end{array}$} & $\begin{array}{l}\text { III.i.a How has the } \\
\text { model been } \\
\text { implemented? }\end{array}$ & The model has been implemented in NetLogo 6.1.1. \\
\hline & & $\begin{array}{l}\text { Ill.i.b Is the model } \\
\text { accessible and if so } \\
\text { where? }\end{array}$ & $\begin{array}{l}\text { The model is available at CoMSES Net: https://www.comses.net/codebases/0f779ef3-5c89-4fe0-be7f- } \\
2757 f 9789028 / \text { releases/1.0.1/ }\end{array}$ \\
\hline & \multirow[b]{2}{*}{ III.ii Initialization } & $\begin{array}{l}\text { Ill.ii.a What is the } \\
\text { initial state of the } \\
\text { model world, i.e. at } \\
\text { time } t=0 \text { of a } \\
\text { simulation run? }\end{array}$ & $\begin{array}{l}\text { At the beginning of each simulation, households are initialized with initial budget and insurance status. } \\
\text { Shock type and households' transfer behavior is defined according to the chosen scenarios (see III.iv). }\end{array}$ \\
\hline & & $\begin{array}{l}\text { Ill.ii.b Is } \\
\text { initialization always } \\
\text { the same, or is it } \\
\text { allowed to vary } \\
\text { among } \\
\text { simulations? }\end{array}$ & $\begin{array}{l}\text { Initialization varies between different scenarios (for details of the implementation of the scenarios see } \\
\text { III.iv.a). }\end{array}$ \\
\hline
\end{tabular}




\begin{tabular}{|c|c|c|}
\hline & $\begin{array}{l}\text { III.ii.c Are the initial } \\
\text { values chosen } \\
\text { arbitrarily or based } \\
\text { on data? }\end{array}$ & Initial values are arbitrarily chosen. \\
\hline III.iii Input Data & $\begin{array}{l}\text { III.iii.a Does the } \\
\text { model use input } \\
\text { from external } \\
\text { sources such as } \\
\text { data files or other } \\
\text { models to represent } \\
\text { processes that } \\
\text { change over time? }\end{array}$ & The model does not use input data to represent time-varying processes. \\
\hline III.iv Submodels & $\begin{array}{l}\text { III.iv.a What, in } \\
\text { detail, are the } \\
\text { submodels that } \\
\text { represent the } \\
\text { processes listed in } \\
\text { 'Process overview } \\
\text { and scheduling'? }\end{array}$ & $\begin{array}{l}\text { Setup processes } \\
\text { Function name: setup } \\
\text { Household setup } \\
\text { Function name: setup-households } \\
N_{\mathrm{H}} \text { households are created and initialized with an initial budget } Y^{0} \text {. Initial budget and income level is the } \\
\text { same for all households. A shock series is determined for the simulated time span } T \text {. The calculation of } \\
\text { the shock series is different for idiosyncratic shocks hitting the households independently and covariate } \\
\text { shocks affecting many households at the same time: } \\
\text { - Idiosyncratic shocks: For each household, the shock series is determined individually. Shocks } \\
\text { occur with probability } p_{\mathrm{s}} \text {. } \\
\text { Covariate shocks: A shock series is determined for the whole village. Shocks occur with probability } \\
\quad p_{\mathrm{V}}=p_{\mathrm{S}} / p_{\mathrm{H}} \text {. In time steps where the village is affected by a shock, individual households are } \\
\text { affected with probability } p_{\mathrm{H}} \text {. This results in an overall shock probability } p_{\mathrm{s}}=p_{\mathrm{V}} \times p_{\mathrm{H}} \text { for an individual } \\
\text { household. We distinguish between cases in which all households without exception are affected by } \\
\left.\left.\text { the shock ( } p_{\mathrm{H}}=1\right) \text { and cases in which some households are exempted ( } p_{\mathrm{H}}=0.8\right) \text {, for example by } \\
\text { a more favorable geographical location in case of floods or an agricultural management strategy } \\
\text { more adapted to drought risks. } \\
\text { To make the strategies comparable, in one repetition the shock series of one specific household is the } \\
\text { same for every risk-coping instrument. } \\
\text { Network setup } \\
\text { Function name: create-small-world-network } \\
\text { A small-world network is generated using the generate-watts-strogatz primitive in the NetLogo Nw } \\
\text { Extension which is based on the Watts-Strogatz model (Watts and Strogatz, 1998). Essentially, the } \\
\text { algorithm creates a ring of households with each node connected to } N_{\mathrm{N}} \text { nodes on either side. Each link } \\
\text { is rewired with rewiring probability } p_{\mathrm{r}} \text {. To allow for the control of the transfers in both directions of a link }\end{array}$ \\
\hline
\end{tabular}




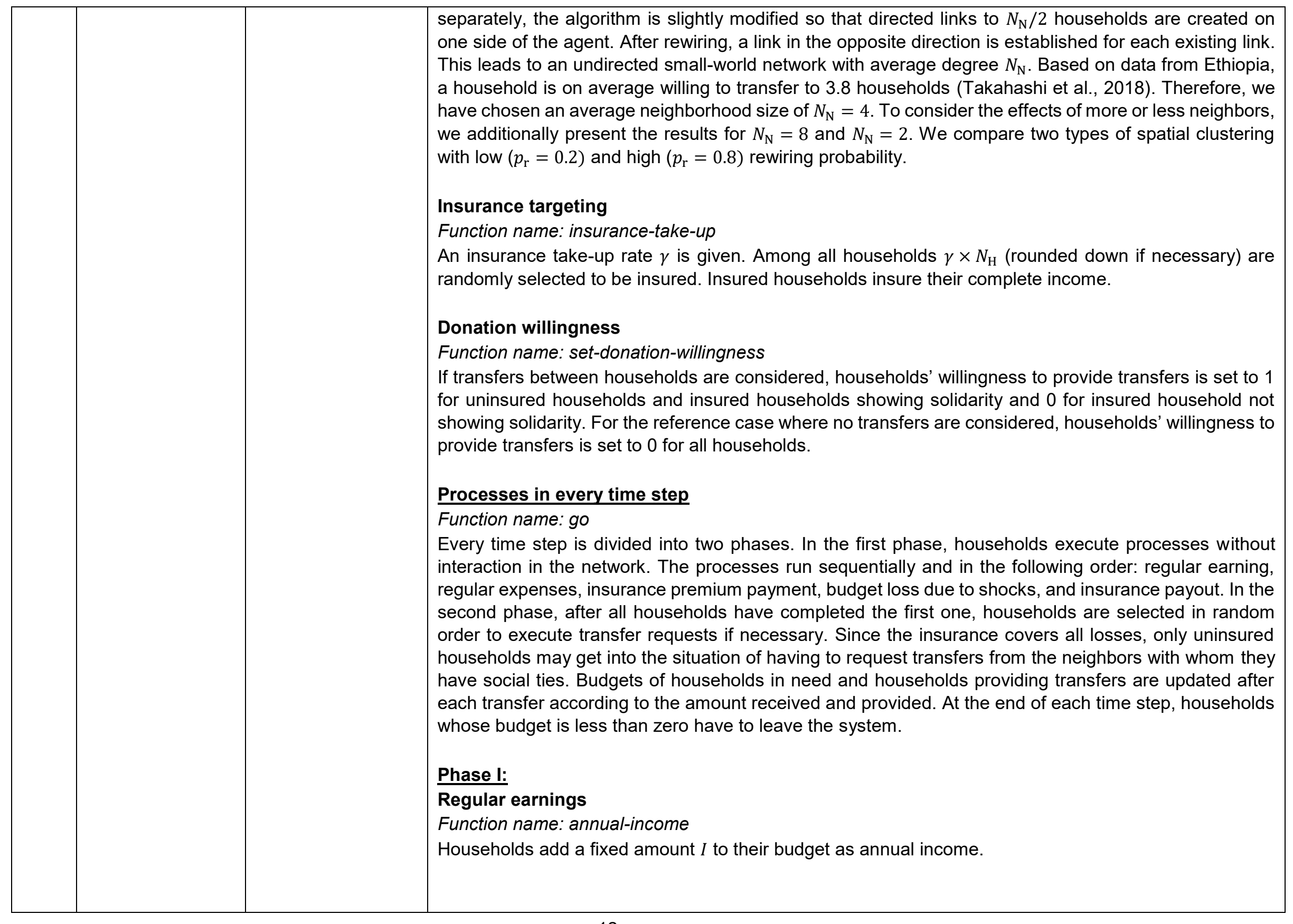




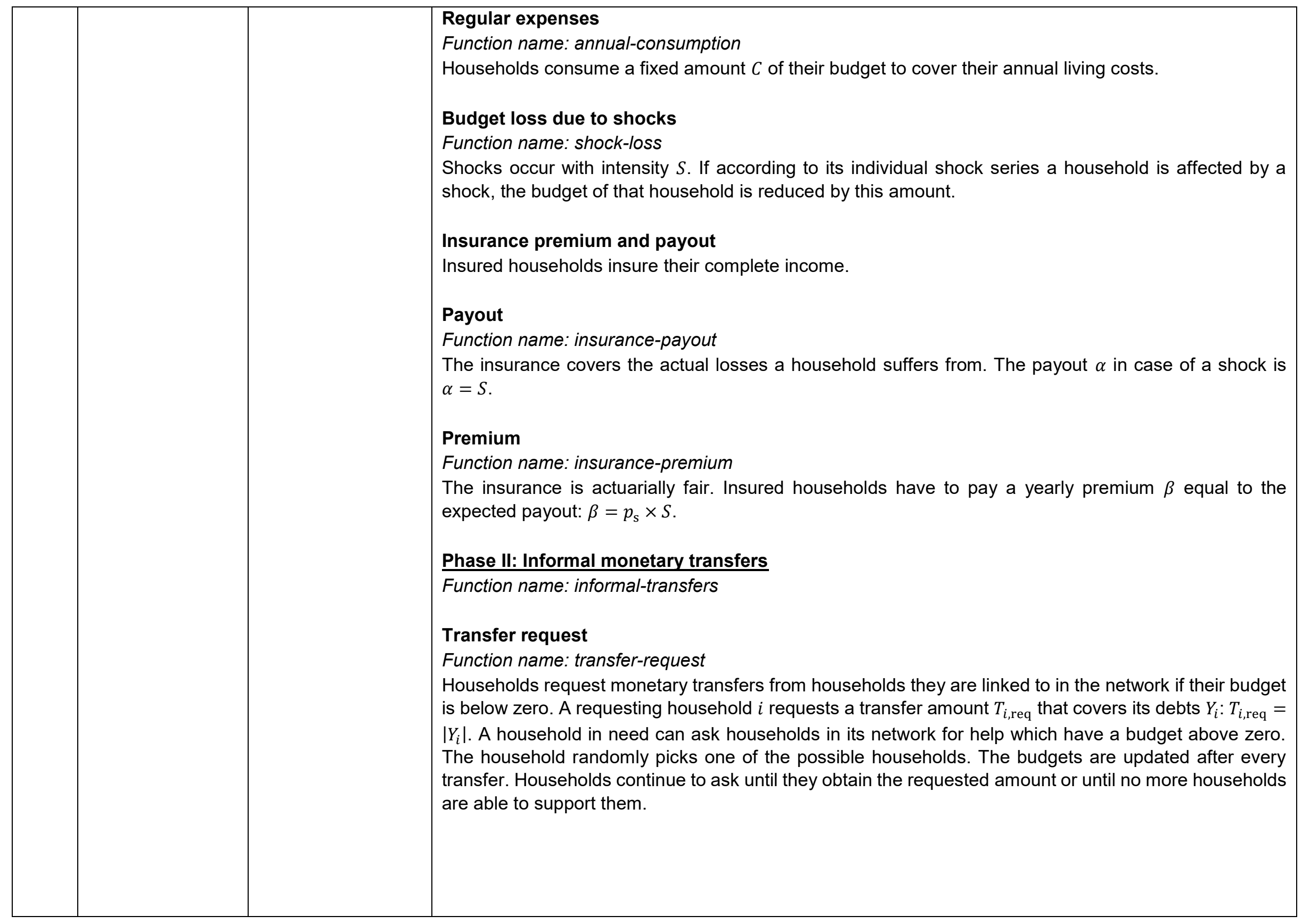




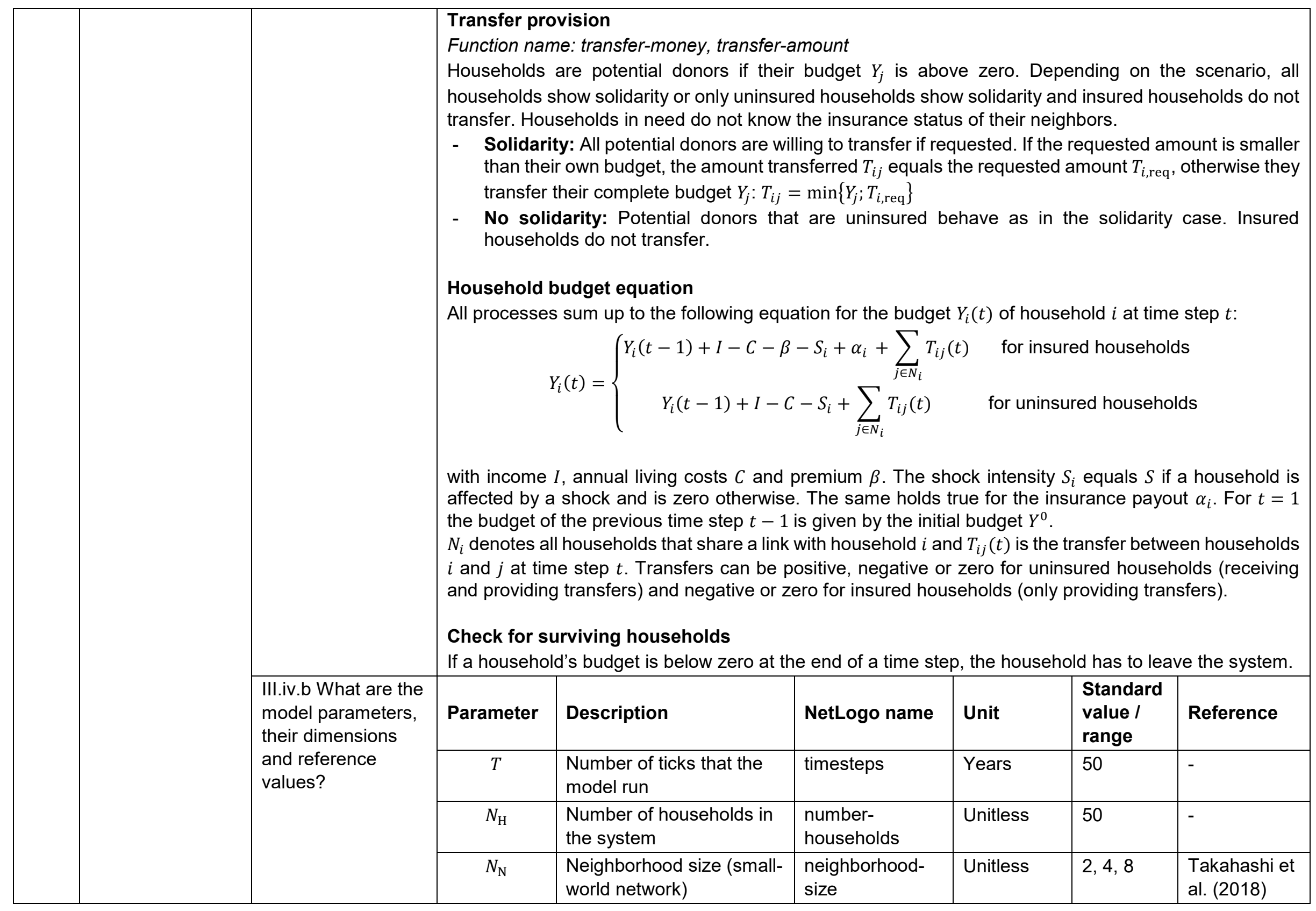




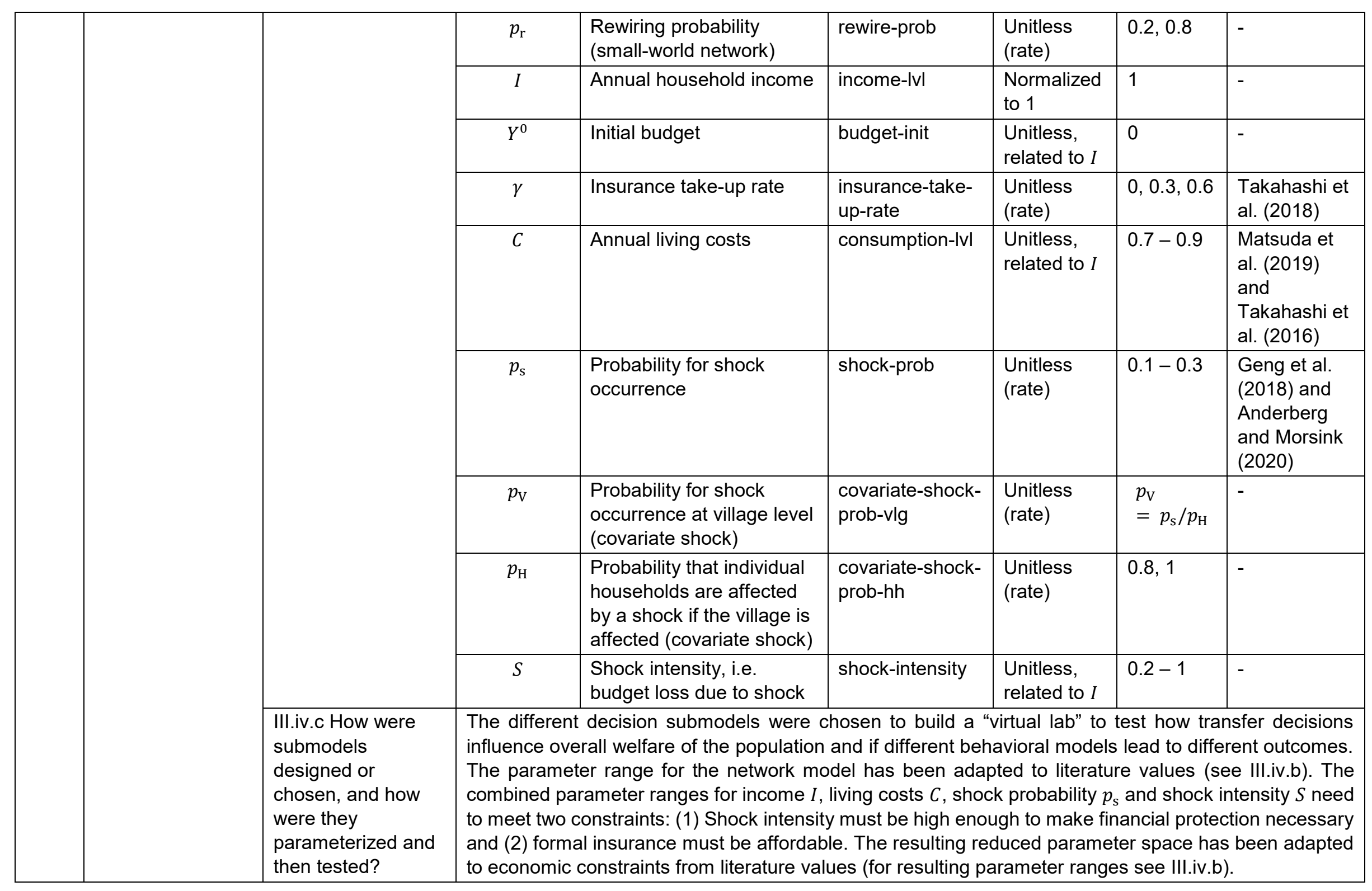




\section{References}

Anderberg, D., Morsink, K., 2020. The introduction of formal insurance and its effect on redistribution. Journal of Economic Behavior \& Organization 179, 22-45.

Geng, X., Janssens, W., Kramer, B., List, M. van der, 2018. Health insurance, a friend in need? Impacts of formal insurance and crowding out of informal insurance. World Development $111,196-210$.

Matsuda, A., Takahashi, K., Ikegami, M., 2019. Direct and indirect impact of index-based livestock insurance in Southern Ethiopia. The Geneva Papers on Risk and Insurance - Issues and Practice 44, 481-502.

Müller, B., Bohn, F., Dreßler, G., Groeneveld, J., Klassert, C., Martin, R., Schlüter, M., Schulze, J., Weise, H., Schwarz, N., 2013. Describing human decisions in agent-based models ODD + D, an extension of the ODD protocol. Environmental Modelling \& Software 48, 3748.

Salecker, J., Sciaini, M., Meyer, K.M., Wiegand, K., 2019. The NLRX R package: A nextgeneration framework for reproducible NetLogo model analyses. Methods in Ecology and Evolution 10, 1854-1863.

Takahashi, K., Barrett, C.B., Ikegami, M., 2018. Does Index Insurance Crowd In or Crowd Out Informal Risk Sharing? Evidence from Rural Ethiopia. American Journal of Agricultural Economics 101.

Takahashi, K., Ikegami, M., Sheahan, M., Barrett, C.B., 2016. Experimental Evidence on the Drivers of Index-Based Livestock Insurance Demand in Southern Ethiopia. World Development 78, 324-340.

Watts, D.J., Strogatz, S.H., 1998. Collective dynamics of 'small-world' networks. Nature 393, 440442. 